\title{
TINJAUAN PERSPEKTIF FIKIH TERHADAP PELAKSANAAN MAHAR DALAM PERNIKAHAN
}

\author{
Nazil Fahmi \\ Program Studi Ahwal Syakhsiyyah Pascasarjana UIN Datokarama Palu \\ Email: nazilfahmi1998@gmail.com
}

\begin{abstract}
The process of marriage in Islam starting from the engagement stage to the reception is very much considered in every process. One part that is quite interesting in Islam is the dowry. Dowry is a form of gift that must be held in marriage issued by a man to a woman. Another definition of dowry is a full right that must be given to women as a form of respect for women in Islam as well as a form of responsibility and seriousness of a man to marry. From this description, this study chose library research as the research method and character analysis as the approach. Furthermore, as a result of this scientific study, in the perspective of fiqh, the views of the jurists differed in opinion, for example, the jurists, especially the jurists from the four schools of thought, had different opinions about the amount of the dowry and the payment and giving of the dowry. However, from the differences of each cleric, of course, his thoughts direct the benefits of applying dowry in Islamic law.
\end{abstract}

Keywords: Merriage, Dowry, Jurists, Differed in opinion

\begin{abstract}
Abstrak
Proses pernikahan dalam Islam mulai dari tunangan sampai tahapan resepsi sangat diperhatikan dalam setiap prosesinya. Salah satu bagian yang cukup menarik perhatian dalam Islam adalah mahar. Mahar merupakan salah satu bentuk pemberian yang wajib diadakan dalam pernikahan yang dikeluarkan oleh seorang laki-laki kepada seorang perempuan. Definisi lain dari mahar adalah hak penuh yang harus diberikan kepada perempuan sebagai bentuk menghargai kedudukan perempuan dalam Islam serta bentuk tanggung jawab dan keseriusan seorang laki-laki untuk menikah. Dari uraian tersebut, kajian ini memilih penelitian pustaka sebagai metode penelitian dan analisis pemikiran tokoh sebagai pendekatan penelitian. Selanjutnya, sebagai hasil kajian ilmiah ini adalah dalam perspektif fikih utamanya pandangan para ulama fukaha mempunyai perbedaan pendapat, misalnya ulama fukaha khususnya ulama empat mazhab memiliki perbedaan pendapat tentang kadar mahar dan pembayaran serta pemberian mahar. Tetapi dari perbedaan setiap ulama tentunya pemikirannya mengarahkan kemaslahatan pada penerapan mahar di dalam syariat Islam.
\end{abstract}


Kata Kunci: Pernikahan, Mahar, Ulama Fukaha, Perbedaan Pendapat

\section{A. Pendahuluan}

Institusi terkecil dalam lingkungan masyarakat yang berperan penting dalam pembentukan generasi yang berkualitas adalah keluarga. Pernikahan bukan saja merupakan jalan yang amat mulia yang telah ditakdirkan oleh Allah swt. untuk membimbing keluarga dalam rumah tangga, tetapi pernikahan juga sebagai sarana untuk memperkenalkan serta menyatukan hubungan keluarga satu dengan keluarga lain, dan tujuannya sebagai jalan untuk menguatkan ikatan hubungan keluarga satu dengan keluarga lain. ${ }^{1}$ Demikian yang dijabarkan oleh Muhammad Abu Ishrah yang memberikan definisi pernikahan yang lebih luas, serta Zakiah Daradjat juga mengutip perkataannya yang menjabarkan bahwa pernikahan adalah akad yang memberikan keuntungan untuk membolehkan secara hukum adanya hubungan kekeluargaan antara laki-laki dan perempuan saling tolongmenolong dan membatasi hak dan pemenuhan kewajiban masing-masing. ${ }^{2}$

Dengan demikian, ikatan pernikahan adalah yang paling kuat dalam kehidupan manusia, tidak hanya antara suami dan istri serta keturunannya, tetapi antara dua keluarga. Jadi, kemaslahatan terbesar dari pernikahan adalah untuk melindungi wanita yang dianggap lemah dari kehancuran. Karena seorang wanita, setelah menikah, maka suaminya bertanggung jawab atas pemeliharaannya dengan cara memberikan nafkah kepada istri. ${ }^{3}$ Sebelum akad diucapkan oleh suami untuk menghalalkan seorang perempuan untuk dijadikan pendamping hidup dalam kehidupan, maka dalam ajaran Islam sangat peduli dan menghormati wanita di dalam dirinya

${ }^{1}$ Sulaiman Rasjid, Fiqh Islam (Hukum Fiqh Islam), Cet. ke-2 (Bandung: PT Sinar Baru Algensindo), 374.

2 Abd. Rahman Ghazaly, Fiqh Munakahat, ed. by Kreasindo, Cet. Ke-1 (Bogor: Kencana, 2003), 9.

${ }^{3}$ Sulaiman Rasjid, Fiqh Islam (Hukum Fiqh Islam),... 375. 
memberikan hak termasuk menerima mahar. ${ }^{4}$ Mahar adalah istilah yang menunjukkan pada harta sebagai kepemilikan hak seorang perempuan dalam ikatan pernikahan yang disahkan pada satu akad, sebagai bentuk ganti rugi karena memiliki hak untuk bersenang-senang serta diperbolehkan untuk melakukan berhubungan badan secara benar, dan tidak menjadikan kedudukan pernikahan yang rusak. Diketahui Islam tidak memandang mahar sarana sebagai nilai harga kepada perempuan, tetapi Islam memandang mahar sebagai bentuk sarana keseriusan seorang laki-laki untuk memiliki perempuan. ${ }^{5}$

Mazhab Asy-Syafi'i mendefinisikan mahar sebagai sesuatu yang wajib karena pernikahan atau pemenuhan hak secara sah untuk berhubungan badan, karena pemaksaan penghilangan hak untuk berhubungan badan pada bagian dari suami, atau karena khulu' serta kesaksian. Jadi, apa yang diwajibkan dari laki-laki untuk perempuan disebut mahar. Selanjutnya istilah mahar termasuk yang disyaratkan karena ada pernikahan yang sah dan yang disyaratkan karena persetubuhan, baik dalam akad yang rusak, dipertanyakan, atau paksa. Jadi makna mahar dalam arti lebih tepat daripada makna mahar menurut istilah syari'at, karena arti mahar menurut syariat termasuk apa yang diberikan kepada wanita untuk menghalalkan berhubungan badan karena keraguan dan lain-lain. ${ }^{6}$

Mengenai kebolehan untuk memiliki perempuan sebagai istri dengan pemberian mahar sebagai bagian hak perempuan dalam pandangan syariat Islam, maka perlu juga memahami adanya pertimbangan dasar hukum serta perdebatan dari kalangan ulama fikih mengenai hal ini. Karena Alquran merupakan bukti keberadaan Islam dan merupakan prinsip konstruksinya, sebagai konstitusi dasar yang mengarah pada hukum Islam. Sedangkan

\footnotetext{
${ }^{4}$ Abd. Rahman Ghazaly, Fiqh Munakahat, ... 84.

5 Ibnu Irawan, Jayusman, "Mahar Hafalan Al-Qur'an Perspektif Hukum Islam", PALITA: Journal of Social-Religion Research, Vol. 04. No. 02 (2019), 122.

${ }^{6}$ Syaikh Abdurrahman Al-Juzairi, Fikih Empat Mazhab (Jilid 5), (Jakarta: Pustaka AlKautsar, t.th.), 196-198.
} 
Sunnah adalah penjelasan rinci tentang konstitusi, baik hal-hal yang teoritis maupun aplikasi praktisnya. ${ }^{7}$ Di sisi lain perdebatan akan kajian mahar dalam hasil pemikiran kalangan ulama fikih yang dikemas pada eksistensi fikih dalam Islam sampai saat ini belum mendapatkan titik temu, utamanya permasalah mengenai ukuran atau kadar mahar yang masih terdapat perdebatan di antara ulama satu dengan ulama lainnya. ${ }^{8}$ Oleh karena itu, dengan uraian di atas menarik untuk dikaji dalam satu kajian ilmiah yakni tinjauan perspektif fikih terhadap pelaksanaan mahar dalam pernikahan.

\section{B. Metode Penelitian}

Penelitian ini menggunakan penelitian pustaka merupakan salah satu pilihan metode yang digunakan dalam penelitian ini. Penggunaan pendekatan analisis serta pembanding antara perspektif para fukaha yang berbeda mengenai mahar merupakan arah dari pendekatan yang digunakan oleh peneliti. Bermaksud untuk menggunakan pendekatan ini dalam penelitian yakni agar menjabarkan serta menelaah terhadap fenomena mahar yang sering terjadi di kehidupan masyarakat, utamanya untuk memahami nilai, kadar atau ukuran sebagai patokan mahar untuk diberikan kepada perempuan. Selanjutnya, dengan penelitian mampu mengetahui dari kejelasan status hukum yang membanding perspektif berbeda yang terjadi dikalangan para fukaha mengenai mahar. Data dan sumber data yang diperoleh dari penelitian ini melalui sumber kepustakaan secara elektronik dan non elektronik, serta data yang ditemukan melalui teknik editing, organizing, dan finding akan dikelolah melalui penganalisaan data secara komparatif (pembanding).

\footnotetext{
7 Alfiah, Fitriadi, Suja'i, Studi Ilmu Hadis, Cet. Tahun 2016, (Pekanbaru: Kreasi Edukasi, 2016), 29.

${ }^{8}$ Subhan, "Nalar Kesetaraan Mahar Dalam Perspektif Syariah Islam", At-Turās: Jurnal Studi Keislaman, Vol. 04. No. 01 (2017), 8.
} 


\section{Pembahasan}

\section{Terminologi Mahar}

Harta baik berupa uang atau barang yang dipenuhi hak dari perempuan yang diberikan oleh laki-laki saat kontrak pernikahan berlangsung merupakan definisi mahar secara etimologi dalam perspektif KBBI. ${ }^{9}$ Mahar berarti juga maskawin. ${ }^{10}$ Secara etimologi syariah, mahar dapat diistilahkan sebagai shadaq yang berarti ketulusan atau kejujuran. Jika diperhatikan secara tegas, bahwa mahar merupakan salah satu tanda ketulusan dan kejujuran dari seorang laki-laki untuk memiliki seorang perempuan sebagai pendamping dalam keluarga (istri). Perlu diketahui mahar bukan sebagai tanda nilai harga untuk memiliki seorang perempuan, tetapi mahar merupakan pemberian sebagai tanda untuk menghargai kedudukan perempuan yang di mana pemberian seorang laki-laki baik berupa uang atau barang yang menjadi hak penuh bagi seorang perempuan untuk menerimanya. ${ }^{11}$ Ulama dari kalangan hanafiyah menjabarkan definisi dari mahar merupakan pemberian harta yang diwajibkan dikeluarkan oleh suami saat akad nikah berlangsung sebagai tanda diterimanya untuk menikmati berhubungan badan. ${ }^{12}$ Imam Malik menjelaskan definisi mahar sebagai bentuk persyaratan yang sah akibat terjadinya pernikahan, serta mahar merupakan bagian rukun pernikahan dan hukumnya wajib ada dan diberikan kepada berhak menerimanya. ${ }^{13}$

Ibrahim Muhammad al-Jamal mengatakan mahar adalah pemberian sesuai kemampuan seorang laki-laki kepada seorang perempuan, dan

${ }_{9}^{9}$ Depdiknas, Kamus Besar Bahasa Indonesia, (Jakarta: Balai Pustaka, 2002), 696.

10 Ahmad Warson Munawwir, Kamus Al-Munawwir Arab-Indonesia Terlengkap, (Yogyakarta: Pustaka Progressif, 1997), 1363.

11 Saleh Al- Fauzan, Al-Mulakhkhasul Fiqhi, ed. by Terj. Abdul Hayyie Al-Kattanie, et.al., (Jakarta: Gema Insani, 2006), 672.

12 Amir Syarifuddin, Hukum Perkawinan Islam Di Indonesia, Edisi 1, Cet. ke-2, (Jakarta: Kencana, 2007), 85.

13 Husein Muhammad, Fiqh Perempuan, Refleksi Kiai Atas Wacana Agama Dan Gender, Cet. ke-2 (Yogyakarta: LKIS, 2007), 148. 
perempuan terpenuhi haknya serta menyukai pemberian dari seorang lakilaki tersebut. Prinsip mahar yang didefinisikan oleh Ibrahim Muhammad alJamal adalah prinsip tidak berlebih-lebihan dalam pemberian mahar. sebab pemberian mahar pada hakikatnya bukan dipandang dari nilai materialnya, tetapi dengan mahar telah mengetahui kemampuan seorang laki-laki yang mempunyai kejujuran untuk menikah dengan seorang perempuan. ${ }^{14}$ Sementara pengertian mahar dalam perspektif KHI yang menyebutkan pada pasal 1 huruf d merupakan pemberian dari seorang laki-laki kepada seorang perempuan, baik pemberiannya berupa uang, barang, atau jasa selagi tidak bertentangan dengan syariat Islam. ${ }^{15}$ Penjabaran mengenai makna mahar baik makna secara etimologi atau terminologi dari persepektif ulama atau konstitusi dapat ditarik kesimpulan bahwa mahar merupakan pemberian yang wajib diberikan oleh seorang laki-laki sebagai calon suami kepada seorang perempuan sebagai calon istri, serta pemberian yang berupa harta menjadi salah satu hak penuh yang dimiliki oleh seorang perempuan. Maksud pemberian mahar merupakan sarana untuk menghargai kedudukan seorang perempuan, dan menjadi suatu kewajiban yang tidak boleh ditinggal seorang laki-laki jika ingin menikah dengan seorang perempuan.

\section{Mahar dalam Perspektif Fikih}

Persepktif fikih yang memandang mahar merupakan salah satu bagian terpenting dalam pernikahan, bahkan ada kalangan ulama yang menjadikan mahar sebagai salah satu rukun dan syarat sah dalam pernikahan. Karena fikih dapat berubah tergantung pada situasi dan kondisi. Tentunya mahar jika ditelaah melalui pendekatan fikih, maka fikih akan memandang mahar

14 Ibrahim Muhammad al-Jamal, Fiqh Al-Mar'ah Al-Muslimah, ed. by Terj. S. Ziyad 'Abbas, (Jakarta: PT Multi Kreasi Singgasana, 1991), 31.

15 Permata Press, Kompilasi Hukum Islam (KHI), Edisi Terbaru, (Jakarta: Tim Permata Press, 2005), 1. 
sebagai pemahaman yang didasarkan pada prinsip syari'ah ketika telah diterapkan dalam kondisi tertentu. ${ }^{16}$

\section{Kadar Mahar}

Para fukaha sepakat bahwa mahar merupakan bagian dari syarat sahnya pernikahan, serta tegas untuk tidak boleh meniadakan mahar dalam sebuah pernikahan. Sebab didasarkan daripada firman Allah swt.17 dalam Alquran Surat An-Nisa (4) ayat 4:

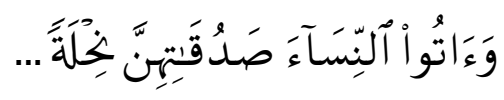

Terjemahnya:

Berikanlah maskawin (mahar) kepada wanita (yang kamu nikahi) sebagai pemberian dengan penuh kerelaan... ${ }^{18}$

Maskawin harus diterima oleh wanita dan tidak memberikan hak kepada orang tua atau saudara kandungnya. Serta maskawin adalah penyeimbang untuk menikmati tubuh wanita dan tanda kesediaannya untuk digauli dengan suaminya. Selain itu, mahar mempererat tali silaturrahmi dan membawa rasa cinta wanita kepada suaminya sebagai pasangan hidup. ${ }^{19}$ Sementara itu, kalangan ulama masih memperdebatkan boleh atau tidaknya untuk mempersyaratkan kadar mahar. Di sisi lain, jika kembali pada redaksi hadis yang memandang kadar mahar tidak dapat diukur, sehingga kemerdekaan dapat dijadikan mahar. Dengan hal ini, para fukaha mempunyai perbedaan pendapat mengenai kadar dari mahar. Berikut di bawah ini penjelasannya:

${ }^{16}$ Agus Supriyanto, "Ijtihad: Makna Dan Relasinya Dengan Syari'ah, Fiqih, Dan Ushul Fiqih", Maslahah: Jurnal Hukum Islam Dan Perbankan Syari'ah, Vol. 01.No. 01 (2010), 4.

17 Ibnu Rusyd, Bida>yatu 'I-Mujtahid, ed. by terj. M.A. Abdurrahman, A. Haris Abdullah, Tarjamah Bidayatu 'I-Mujtahid, Cet. ke-1 (Semarang: CV. Asy Syifa', 1990), 385.

18 Kementerian Agama, Al-Qur'an Dan Terjemahannya (Mushaf Fatimah), (Jakarta: PT. Insan Media Pustaka, 2012), 77.

${ }^{19}$ Sa'id Thalib Al-Hamdani, Risalatun Nika>h, ed. by terj. Agus Salim "Risalah Nikah (Hukum Perkawinan Islam), Cet. ke-3, (Jakarta: Pustaka Amani, 2011), 132-133. 
Mahar dalam pandangan ulama mazhab mengalami perbedaan pendapat, utamanya pada pembahasan dengan batasan dalam kadar mahar dalam pelaksanaan mahar. Golongan ulama hanafi berpendapat bahwa batasan minimal pada kadar mahar adalah sepuluh mahar. Selanjutnya, batasan minimal kadar mahar yang disetarakan dengan seperempat emas atau disetarakan dengan tiga dirham perak, serta yang disetarakan dengan kadar dari keduanya, hal ini dipaparkan oleh ulama yang bergolongan Malikiyah. Dua golongan ulama fikih pada generasi empat ulama mazhab lainnya berbeda pendapat dengan ulama Hanafi dan Maliki mengenai batasan minimal mahar. Kedua golongan ulama tersebut menyatakan bahwa batasan minimal mahar tidak dibatasi. Sehingga harta yang dianggap bernilai lebih pantas menjadi mahar daripada mahar yang diukur dari jumlah. ${ }^{20}$ Mahar juga dapat berupa mengajar Alquran, seperti yang diriwayatkan dari Rasulullah saw. beliau menikahkan sahabatnya dengan mahar bacaan Alquran. ${ }^{21}$ Yang demikian pendapat dari Imam Maliki, Imam Syafi'i dan salah satu riwayat Imam Hambali mengatakan "mengajarkan Alquran boleh dijadikan mahar. Sedangkan pendapat Imam Hanafi dan pendapat yang jelas dari Imam Hambali menyebutkan "hal itu tidak boleh dijadikan sebagai mahar". ${ }^{22}$

\section{Syarat Mahar}

Perdebatan yang menghasilkan perbedaan pendapat dikalangan ulama fukaha mengarahkan kepada syarat dalam mahar. Dalam buku Abdurrahman Al-Jaziri disebutkan ada empat syarat yang harus terpenuhi dalam mahar yakni:

1. Mahar yang memiliki harga berharga. Maksudnya mahar tidak lebih diukur pada banyak sedikit harta yang diberikan, yang lebih utama harta

\footnotetext{
20 Al-Kurdiy, Ahkam Al-Mar'ah Fi Al-Fiqh Al-Islami>, (Damaskus: Dar al-Ulum alInsaniyah, 1993).

21 Imam Asy-Syaukhani, Busta>nul Ahba>ri Mukhtasadu Nayli Al-Auth\{a>ri, ed. by terj. “Ringkasan Nailul Authar (Jilid 3)” (Jakarta: Pustaka Azzam, t.th), 493-494.

22 Al-'Allamah Muhammad bin 'Abdurrahman ad-Dimasyqi, Rahmah Al-Ummah Fi Ikh\{tila $>f$ Al-A'immah, ed. by terj. 'Abdullah Zaki Alkaf, Fiqih Empat Mazhab, Cet. ke-18 (Bandung: Hasyimi, 2017).
} 
bernilai harga. Misalnya seorang laki-laki hanya berkemampuan memberikan mahar satu pasang sandal yang jelas nilai harga, lebih baik daripada seorang laki-laki berkemampuan memberikan sepuluh sapi dengan dasar prinsip terpaksa dan berlebih-lebihan, tetapi hal yang demikian tidak jelas nilai harga.

2. Barangnya suci dan dapat bermanfaat. Mahar secara jelas tidak sah diambil dari barang yang tidak suci. Misalnya mahar dari barang berupa darah, babi, minuman yang memang di dalam agama diharamkan yakni minuman khamar atau yang berunsur memabukan dan barangnya yang dapat menghilangkan kesadaran. Hal tersebut tidak ada toleransi untuk dijadikan sebagai mahar, dikarenakan barangnya tidak suci serta tidak bermanfaat juga. Permisalan lain mengenai syarat ini, jika ada barangnya tidak suci tetapi dapat memberikan manfaat, maka kedudukan mahar tersebut masih diperdebatkan dalam kalangan para ulama tentang boleh dan tidaknya menggunakan barang yang dimaksud tersebut.

3. Maskawin yang bukan bersumber dari barang hasil ghasab. Jelas dan tegas bahwa mahar tidak dibenarkan dari barang ghasab. Walaupun dari pengertian hal tersebut mengarah kepada barang yang diambil dari orang lain tanpa izinnya, tetapi tidak berniat sama sekali untuk memilikinya dan berniat untuk mengembalikannya.

4. Tidak sah dijadikan mahar jika barangnya tidak jelas keberadaan dan keadaannya. Misalnya seorang laki-laki akan memberikan mahar berupa barang dari hasil penipuan. Karena penipuan merupakan salah satu tindakan yang hasilnya tidak jelas keadaannya. Maka ajaran Islam mengenai persyaratan mahar, secara tegas tidak dibenarkan dalam pelaksanaanya serta tidak sah dalam kedudukan hukumnya. ${ }^{23}$

${ }^{23}$ Abd. Kohar, "Kedudukan Dan Hikmah Mahar Dalam Perkawinan", ASAS: Jurnal Hukum Ekonomi Syariah, Vol. 08. No. 02 (2016), 43-44. 


\section{Dasar Hukum Mahar}

Sebagai sumber utama dasar hukum, Alquran telah tegas dan jelas untuk mengadakan mahar pada proses pernikahan. Hal demikian telah tegas terdapat dalam Surat An-Nisa ayat 4 di dalam Alquran, Allah swt., berfirman:

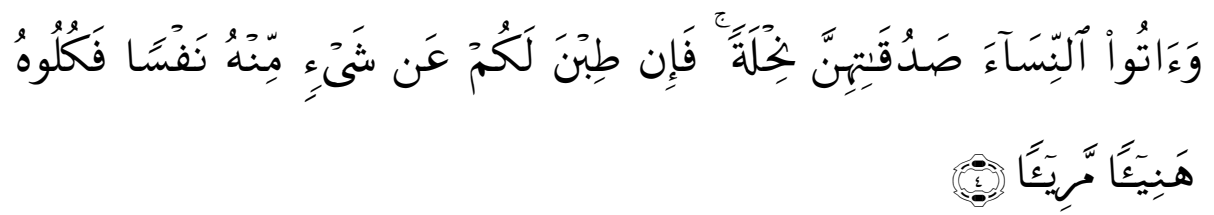

Terjemahnya:

Berikanlah maskawin (mahar) kepada wanita (yang kamu nikahi) sebagai pemberian dengan penuh kerelaan. ${ }^{24}$ Kemudian jika mereka menyerahkan kepada kamu sebagian dari maskawin itu dengan senang hati, Maka makanlah (ambillah) pemberian itu (sebagai makanan) yang sedap lagi baik akibatnya. ${ }^{25}$

Ayat di atas menjelaskan bahwa mahar merupakan salah satu hak keperdataan yang jelas dan tegas dimiliki oleh perempuan. Sehingga mahar yang diterapkan dalam ajaran Islam membuktikan perempuan mempunyai kemuliaan dan kedudukan yang perlu mendapatkan perhatian dari seorang laki-laki. Sekalipun dahulunya saat zaman jahiliyah, perempuan dianggap perumpamaan objek yang dapat diperjual belikan hak nya. Maksudnya perumpamaan ini adalah maskawin yang diberikan oleh laki-laki yang seharusnya menjadi hak kepemilikan dari perempuan, tetapi hak tersebut berpindah kepemilikan yang diambil alih oleh walinya, bahkan wali dari perempuan berhak merampas secara paksa dari perempuannya. Layaknya sistem barter yang buruk telah mencenderai hak kepemilikan dan kedudukan perempuan yang perlu dihargai. ${ }^{26}$ Oleh karena itu, hadis sebagai pondisi utama dasar hukum setelah Alquran, terang-terangan untuk menghargai

\footnotetext{
24 Pemberian itu ialah maskawin yang besar kecilnya ditetapkan atas persetujuan kedua pihak, Karena pemberian itu harus dilakukan dengan ikhlas.

${ }^{25}$ Kementerian Agama, Al-Qur'an Dan Terjemahannya (Mushaf Fatimah), ....77.

${ }^{26}$ Putra Halomoan, "Penetapan Mahar Terhadap Kelangsungan Pernikahan Ditinjau Menurut Hukum Islam", JURIS: Jurnal Ilmiah Syariah, Vol. 14. No. 02 (2015), 110-11.
} 
kedudukan seorang perempuan melalui adanya mahar. Redaksi hadis tersebut adalah sebagai berikut:

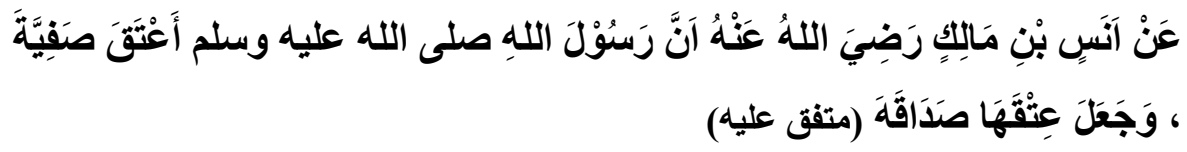

Artinya:

Dari Anas bin Malik r.a, bahwa Nabi saw. memerdekakan Shafiyah dan menjadikan kemerdekaan dirinya sebagai maskawin. (muttafaq 'alaih) ${ }^{27}$

Makna global dari hadis di atas adalah Shafiyah binti Huyai adalah putri salah seorang pemimpin Bani Nadhir, yang sebelumnya menjadi Istri Kinanah bin Abul Haqiq, yang terbunuh saat perang khaibar. Lalu Nabi saw. menaklukkan Khaibar melalui peperangan, sehingga para wanita dan anakanak menjadi tawanan di tangan orang-orang Muslim. Tadinya Shafiyah masuk ke bagian Dihyah bin Khalifah Al-Kilabi, lalu beliau menggantinya dengan yang lain dan memilihnya bagi diri beliau, sebagai upaya menjaga perasaannya sekaligus sebagai rasa kasihan beliau kepadanya, karena kedudukan dirinya yang hilang. Di antara kemurahan hati beliau, dia tidak hanya ditempatkan sebagai budak wanita yang hina karena statusnya sebagai tawanan perang, tapi kedudukannya diangkat. Beliau menyelamatkannya dari kehinaan perbudakan dan menjadikannya salah seorang UmmahatulMukminin. Beliau memerdekakannya lalu menikahinya, dan masakwinnya adalah kemerdekaan dirinya. ${ }^{28}$ Oleh karena itu, penjelasan hadis ini disebutkan bahwa memerdekakan itu boleh dijadikan sebagai mahar, dengan ungkapan apapun hal itu terjadi. Jadi syariat yang diterapkan dalam aspek

27 Faisal bin Abdul Aziz Alu Mubarak, Makhtash\{ul Kala>m Ala Bulug $>h\{l$ Mara>m, Terj. Imam Fauzi Dan Ikhwanuddin Abdillah "Bulughul Maram Dan Penjelasannyaí, Cet. ke-7 (Jakarta: Ummul Qura', 2019), 767.

${ }^{28}$ Abdullah bin Abdurrahman Alu Bassam, Syarah Hadits Pilihan Bukhari-Muslim, ed. by terj. Kathur Suhardi, Cet. ke-13 (Bekasi: PT Darul Falah, 2016), 897. 
ini, menjadikan mahar tidak lagi diukur dengan batasan kadar dari mahar. ${ }^{29}$ Hanya saja dianjurkan untuk diringankan. Terlebih syariat Islam sangat memperhatikan kemaslahatan yang timbul saat pelaksanaan mahar telah dijalankan dalam kehidupan manusia, utamanya dalam kehidupan keluarga. Sebab hal yang demikian akan mengahadirkan kemaslahatan bagi keduanya. Misalnya laki-laki dapat menikahi perempuan, dengan mendapatkan syarat untuk meringankan mahar, sedangkan perempuan juga tetap mendapatkan sisi kemaslahatan dari subtansi mahar yang dimaknai dengan bukti kebenaran serta ketulusan seorang laki-laki untuk menikah dengannya. Serta hadis tersebut sebagai dalil sahnya menjadikan kemerdekaan itu sebagai mahar, yaitu ungkapan yang terjadi yang memberikan pengertian demikian. Perlu dipahami bahwa kandungan hadis mengarahkan pada keberadaan mahar yang diperbolehkan ada dari sisi agama dan dunia. ${ }^{30}$

\section{Pembayaran dan Pemberian Mahar dalam Perspektif Fikih}

Bagi beberapa fukaha tidak membolehkan penundaan pembayaran mahar, dengan alasan karena pernikahan merupakan suatu ibadah. Diperbolehkan pembayaran sebagian mahar dapat dilakukan diawal manakala sebagai syarat ingin melakukan berhubungan badan, hal demikian diungkapkan oleh sebagian ulama fukaha. Selanjutnya Imam Malik memperbolehkan adanya penundaan pembayaran mahar dengan syarat adanya waktu yang membatasi sebagai masa pembayaran mahar, serta waktu telah ditetapkan batasan untuk tenggang pembaranya. Ulama lainnya seperti Al-Auza'I menyebutkan penundaan pembayaran mahar diperbolehkan karena sebab perceraian dan kematian. ${ }^{31}$ Ungkapan ini menjelaskan bahwa mahar dapat dibayarkan sesuai kemampuan atau menyesuaikan dengan keadaan yang merupakan bagian adat masyarakat.

\footnotetext{
${ }^{29}$ Sa'id Thalib Al-Hamdani, Risalatul al-Nika>h, ed. by terj. Agus Salim "Risalah Nikah (Hukum Perkawinan Islam), ... 133. ...896-898.

30 Abdullah bin Abdurrahman Alu Bassam, Syarah Hadits Pilihan Bukhari-Muslim, 31 Ibnu Rusyd, Bida>yatu 'I-Mujtahid, ... 394.
} 
Kemampuan yang dimaksud dalam uraian ini adalah seorang laki-laki yang memiliki kemampuan sesuai keadaan ekonominya. Sebenarnya mahar bukan dinilai dari nilai materil yang diberikan, tetapi dengan pemberian mahar merupakan keseriusan seorang laki-laki menikahi seorang perempuan untuk dijadikan sebagai calon istri. Jadi, dalam ajaran Islam selalu mengarahkan kepada hal yang mendatangkan kemudahan, dengan ini bagi laki-laki ingin memberikan maskawin yang kadarnya nominal tinggi sesuai keinginan calon istri, seorang laki-laki dapat mengangsur maharnya. ${ }^{32}$

Selanjutnya, Imam Malik berpendapat agar memperoleh keabsahan dari pekawinan, mahar harus diberikan separuh seketika itu juga, serta diberikan saat pernikahan. ${ }^{33}$ Berbeda pendapat dengan Imam Hanafi, mahar wajib dibayarkan setelah laki-laki sudah masuk ke rumah perempuan serta tidak Diisyaratkannya mahar ada ketika dilaksanakannya akad nikah. ${ }^{34}$ Sedangkan Imam Syafi'I dan Imam Ahmad ibn Hambali menyatakan mahar dapat dibayar penuh atau sebagian saja saat akad nikah. Jika ketika mahar hanya terbayar separuh maka wajib untuk tidak dilupakan untuk dibayar sebagiannya. Tetapi, jika maskawin telah memenuhi syarat dan cukup, maka mahar tidak diperbolehkan untuk dibayar secara tertunda. ${ }^{35}$

\section{Jatuhhya Mahar}

Mahar dapat jatuh apabila terjadi dari beberapa sebab perpisahan yang diakibatkan selain perceraian yang di mana si perempuan belum digauli atau terjadinya khalwat dengannya, disebabkan khulu' terhadap mahar sebelum terjadi persetubuhan dan setelahnya, pemberian dari semua mahar sebelum terjadi persetubuhan atau setelahnya, serta istri menghibahkan

32 Aspandi, "Mahar Dalam Perkawinan Islam: Analisis pelaksanaan Pembayaran Dan Pemegang Hak Mahar", AL-'ADALAH: Jurnal Syariah Dan HukumIslam, Vol. 05. No. 02, (2020), 253-54.

${ }^{33}$ Abi Abdul Malik bin Anas, Al-Muwattha, (Beirut Libanon: Maktabah Ilmiah), 43.

${ }^{34}$ Al-Himamu Al-Hanafi, Fathul Qhadir, Jilid 8 (Bairut Libanon: Dar al-Kitab Ilmiah, 1995), 237. 318.

35 Al-Imam Asy-Syafi'i, Terjemahan Al-Umm, Jilid 7 (Jakarta: Victory Agencie, 1989), 
semua mahar untuk suami, jika dia adalah orang yang mampu untuk melakukan sumbangan. ${ }^{36}$ Dan mahar gugur keseluruhannya dari suami hingga dia tidak dibebani tanggungan apapun kepada istri dalam semua perpisahan dari pihak perempuan yang terjadi sebelum adanya persetubuhan dan mahar terjadi jatuh secara keseluruhan akibat hukum adanya pembatalan nikah. ${ }^{37}$

\section{Penutup}

Islam memiliki ajaran yang lengkap serta berasaskan prinsip keadilan, tidak memaksa dan mendatangkan kemaslahatan bagi yang melakukan. Hal ini juga yang terjadi pada pelaksanaan mahar dalam pernikahan, Islam datang ke muka bumi dengan mengedepankan ajarannya melalui mahar untuk menghargai kedudukan seorang perempuan, yang selama ini sejak zaman jahiliya perempuan tidak dianggap haknya. Serta yang paling menyedihkan di zaman tersebut adalah perempuan dapat diperjual belikan bahkan selalu mendapatkan diskriminasi atas haknya. Dengan ajaran Islam ini mengajarkan kepada setiap laki-laki untuk menghargai kedudukan perempuan melalui penerapan mahar di dalam pernikahan. Selanjutnya adanya fikih pada setiap pelaksanaan ajaran Islam, mengantarkan posisi fikih dalam praktik mahar yakni perubahan akan kondisi yang dipengaruhi adat dan kebiasaan masyarakat yang tidak terlepas atau terikat kuat dengan pondasi utama dalam nash. Selanjutnya, pemikiran ulama fukaha pada mahar sangatlah menarik perhatian untuk dibahasnya, karena hasil penadapat ulama fukaha di setiap generasi mempunyai perbedaan. Misalnya ulama fukaha mempunyai perbedaan pendapat pada bagian kadar mahar serta cara pembayaran dan pemberian mahar. Hal ini, tidak dipermasalahkan dalam Islam selagi tetap pada pondasi utama yakni alquran dan hadis.

36 Wahbah az-Zuhaili, Fiqih Islam> Wa Adillatuhu (Jilid 9), ed. by terj. Abdul Hayyie al-Kattani, et, al., eds, Fiqih Islam (Jilid 9), Cet. ke-1 (Jakarta: Gema Insani, 2011), 268.

37 Sayyid Sabiq, Fikih Sunnah (Jilid 3), ed. by Tahkik dan Takhrij: Muhammad Nasiruddin Al-Albani (Jakarta: Cakrawala Press, 2008), 423-424. 


\section{DAFTAR PUSTAKA}

Al-Qur'an Dan Terjemahannya (Mushaf Fatimah), Jakarta: PT. Insan Media Pustaka, 2012

Ad-Dimasyqi, Al-'Allamah Muhammad bin 'Abdurrahman, Rahmah Al-Ummah Fi Ikh\{tila $>$ f Al-A'immah, ed. by terj. 'Abdullah Zaki Alkaf, Fiqih Empat Mazhab, Cet. ke-18, Bandung: Hasyimi, 2017

Al- Fauzan, Saleh, Al-Mulakhkhasul Fiqhi, ed. by Terj. Abdul Hayyie AlKattanie, et.al., Jakarta: Gema Insani, 2006

Alfiah, Fitriadi, Suja'i, Studi Ilmu Hadis, Cet. Tahun 2016, Pekanbaru: Kreasi Edukasi, 2016

Al-Hamdani, Sa'id Thalib, Risalatun Nika>h, ed. by terj. Agus Salim "Risalah Nikah (Hukum Pernikahan Islam), Cet. ke-3, Jakarta: Pustaka Amani, 2011

Al-Hanafi, Al-Himamu, Fathul Qhadir, Jilid 8, Bairut Libanon: Dar al-Kitab Ilmiah, 1995

Al-Jamal, Ibrahim Muhammad, Fiqh Al-Mar'ah Al-Muslimah, ed. by Terj. S. Ziyad ' Abbas, Jakarta: PT Multi Kreasi Singgasana, 1991

Al-Juzairi, Syaikh Abdurrahman, Fikih Empat Mazhab (Jilid 5), Jakarta: Pustaka Al-Kautsar, t.th.

Al-Kurdiy, Ahkam Al-Mar'ah Fi Al-Fiqh Al-Islami, Damaskus: Dar al-Ulum alInsaniyah, 1993

Alu Bassam, Abdullah bin Abdurrahman, Syarah Hadits Pilihan BukhariMuslim, ed. by terj. Kathur Suhardi, Cet. ke-13, Bekasi: PT Darul Falah, 2016

Aspandi, "Mahar Dalam Pernikahan Islam : Analisispelaksanaan Pembayaran Dan Pemegang Hak Mahar", AL-ADALAH: Jurnal Syariah Dan HukumIslam, Vol. 05. No. 02, 2020

Asy-Syafi'I, Al-Imam, Terjemahan Al-Umm, Jilid 7, Jakarta: Victory Agencie, 1989

Asy-Syaukhani, Imam, Busta>nul Ahba>ri Mukhtasadu Nayli Al-Auth\{a>ri, ed. by terj. "Ringkasan Nailul Authar (Jilid 3)", Jakarta: Pustaka Azzam, t.th.

Az-Zuhaili, Wahbah, Fiqih Islam> Wa Adillatuhu (Jilid 9), ed. by terj. Abdul Hayyie al-Kattani, et, al., Fiqih Islam (Jilid 9), Cet. ke-1, Jakarta: Gema Insani, 2011 
Depdiknas, Kamus Besar Bahasa Indonesia, Jakarta: Balai Pustaka, 2002

Ghazaly, Abd. Rahman, Fiqh Munakahat, ed. by Kreasindo, Cet. Ke-1, Bogor: Kencana, 2003

Halomoan, Putra, "Penetapan Mahar Terhadap Kelangsungan Pernikahan Ditinjau Menurut Hukum Islam”, JURIS: Jurnal Ilmiah Syariah, Vol. 14. No. 02, 2015

Ibnu Irawan, Jayusman, "Mahar Hafalan Al-Qur'an Perspektif Hukum Islam", PALITA: Journal of Social-Religion Research, Vol. 04. No.02, 2019

Kohar, Abd., "Kedudukan Dan Hikmah Mahar Dalam Pernikahan", ASAS: Jurnal Hukum Ekonomi Syariah, Vol. 08. No. 02, 2016

Malik bin Anas, Abi Abdul, Al-Muwattha, Beirut Libanon: Maktabah Ilmiah, t.th.

Mubarak, Faisal bin Abdul Aziz Alu, Makhtash\{ul Kala>m Ala Bulug $>h\{l$ Mara $>m$, Terj. Imam Fauzi Dan Ikhwanuddin Abdillah "Bulughul Maram Dan Penjelasannyaí, Cet. ke-7, Jakarta: Ummul Qura', 2019

Muhammad, Husein, Fiqh Perempuan :Refleksi Kiai Atas Wacana Agama Dan Gender, Cet. ke-2, Yogyakarta: LKIS, 2007

Munawwir, Ahmad Warson, Kamus Al-Munawwir Arab-Indonesia Terlengkap, Yogyakarta: Pustaka Progressif, 1997

Permata Press, Kompilasi Hukum Islam (KHI), Edisi Terbaru, Jakarta: Tim Permata Press, 2005

Rasjid, Sulaiman, Fiqh Islam (Hukum Fiqh Islam), Cet. ke-2, Bandung: PT Sinar Baru Algensindo, t.th.

Rusyd, Ibnu, Bida>yatu 'I-Mujtahid, ed. by terj. M.A. Abdurrahman, A. Haris Abdullah, Tarjamah Bidayatu 'I-Mujtahid, Cet. ke-1, Semarang: CV. Asy Syifa', 1990

Sabiq, Sayyid, Fikih Sunnah (Jilid 3), ed. by Tahkik dan Takhrij: Muhammad Nasiruddin Al-Albani, Jakarta: Cakrawala Press, 2008

Subhan, "Nalar Kesetaraan Mahar Dalam Perspektif Syariah Islam”, At-Turāṡ: Jurnal Studi Keislaman, Vol. 04. No. 01, 2017

Supriyanto, Agus, "Ijtihad: Makna Dan Relasinya Dengan Syari'ah, Fiqih, Dan Ushul Fiqih", Maslahah: Jurnal Hukum Islam Dan Perbankan Syari'ah, Vol. 01. No. 01, 2010

Syarifuddin, Amir, Hukum Pernikahan Islam Di Indonesia, Edisi 1, Cet ke-2, Jakarta: Kencana, 2007 